\title{
Mortality from lung cancer among a cohort of nickel cadmium battery workers: $1946-84$
}

\author{
T SORAHAN
}

From the Cancer Epidemiology Research Unit, Department of Social Medicine, University of Birmingham, Edgbaston, Birmingham B15 2TH, UK

ABSTRACT The lung cancer mortality experienced by a cohort of 3025 workers from a nickel cadmium battery factory during the period 1946-84 has been investigated. Occupational histories were described in terms of 75 jobs: eight with "high," 14 with "moderate" or slight, and 53 with minimal or zero exposure to cadmium oxide (hydroxide) dust. The Mantel-Haenszel technique applied to prospective (or historical prospective) studies was used to compare the estimated cadmium exposures (durations of exposed employment) of those dying from lung cancer with those of matching survivors in the same year of follow up, while controlling for sex and year, and age of starting employment. Among workers first employed in the period 1923-46, there was some evidence of an association between the risk of dying from lung cancer and duration of employment in "high or moderate" exposure jobs, although the evidence relied heavily on the findings for the single highest exposure category. Among workers first employed in the period 1947-75, there was no evidence whatsoever of such an association.

In 1976 Lemen etal reported an overall excess mortality from cancers of the respiratory system among a cohort of cadmium smelter workers (expected $=5 \cdot 11$, observed $=12, \mathrm{p}<0 \cdot 05) .{ }^{1}$ In an updated analysis of a larger cohort from the same plant Thun et al also reported excess mortality from cancers of the respiratory system (expected 12.15, observed $=20, p<0.05) .^{2}$ Overall, new information from this study thus consists of eight observed deaths with an expectation of 7.04. Thun et al, however, were also able to estimate individual workers' cumulative exposure to cadmium and they reported a statistically significant trend of increasing risk of death from lung cancer across three exposure groups. ${ }^{2}$

Holden reported a non-significant deficit for dying from cancers of the respiratory system among his group of cadmium workers (expected $=13 \cdot 14$, observed $=10$ ) and a significant excess among his group of "vicinity" workers (expected $=26.08$, observed $=36){ }^{3}$

Armstrong and Kazantzis reported findings for lung cancer for the following exposure groups: "ever high" (expected $=4.4$, observed $=5$ ), "ever medium" (expected $=24 \cdot 2$, observed $=27$ ), and "always low" (expected $=157 \cdot 0$, observed $=167) .{ }^{4}$ Given the numbers of deaths, the SMRs for these three groups were similar 113, 112, and 106 respectively).

In an earlier report of mortality among the cohort of nickel cadmium battery workers described in this paper Sorahan and Waterhouse reported increased SMRs for cancers of the respiratory system among men in the two entry cohorts considered (first employed 1923-46, expected $=42 \cdot 4$, observed $=52$, SMR = 123; first employed 1947-75, expected $=$ $25 \cdot 6$, observed $=35$, SMR $=137){ }^{5}$ They did not find a statistically significant association between duration of employment in high exposure jobs and the risk of dying from cancers of the respiratory system, although such an association was found for duration of employment in high or moderate exposure jobs. No such association was found, however, for those first employed in the period 1947-75 and exposure to oxyacetylene welding fumes and nickel hydroxide dust were important confounding exposures.

The present report provides an updated and detailed analysis of mortality from lung cancer using the Mantel-Haenszel technique applied to prospective (or historical prospective) studies. ${ }^{67}$

\section{Factory conditions}

The nickel cadmium battery factory under investi803 
Table 1 Study population: vital status at end of survey (31 December 1984)

\begin{tabular}{lcr}
\hline & No & $\%$ \\
\hline Traced alive (NHSCR) & 1957 & $64 \cdot 7$ \\
Traced alive (NI) & $48^{*}$ & $1 \cdot 5$ \\
Traced alive: still employed & 3 & $0 \cdot 1$ \\
Deaths $\geqslant 1946$ & $843 \dagger$ & 27.9 \\
Deaths <1946 & $16 \ddagger$ & $0 \cdot 5$ \\
Embarkations $\geqslant 1946$ & $77^{\ddagger}$ & $2 \cdot 5$ \\
Embarkations $<1946$ & $3 \ddagger$ & $0 \cdot 1$ \\
No trace & $78 \S$ & $2 \cdot 6$ \\
Total & 3025 & $100 \cdot 0$ \\
\hline
\end{tabular}

*Only traced to 30 June 1980 .

†Includes two deaths, cause not known.

$\ddagger$ These workers make no contributions to observed or expected numbers.

§Includes 32 workers who left employment before 1 January 1946

who make no contributions to observed or expected numbers.

gation had been originally two concerns that amalgamated in 1947, factory A which opened in 1937 and factory B which opened in 1923 and closed after the amalgamation. The nature of the occupational exposure to cadmium has been reported elsewhere ${ }^{\mathbf{9}}$ : it takes the form of cadmium oxide (hydroxide) dust and in the early factories there was little local exhaust ventilation.

\section{Study population}

The study population has been described elsewhere $^{5-10}$ but may be summarised as 3025 workforce employees (2559 men and 466 women) who started employment at any time in the period 1923-75 and had a minumum period of employment of one month. Employees first hired as office staff are not considered here to be workforce employees.

The Office of Population Censuses and Surveys (OPCS) provided information on the vital status of each individual on the closing date of the survey,

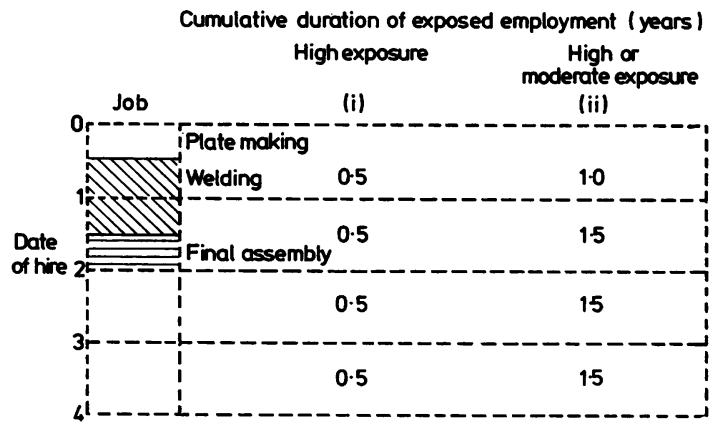

Derivation of exposure estimates: above worker is employed initially in platemaking, after six months transfers to welding, after further 12 months transfers to final assembly, and after further six months leaves employment.
31 December 1984 (table 1). For those who had died, $\overline{\overline{0}}$ a death certificate was obtained with the underlying cause of death coded to the 8th revision of the $\mathbb{D}$ International Classification of Diseases. Mortality was investigated for the period 1 January 1946 to $\underset{\overrightarrow{0}}{\vec{F}}$ 31 December 1984. Those employees who are not in $\overline{0}$ the "observational field" for any part of this period $\frac{C}{0}$ (and they include three employees who emigrated and $\overline{\bar{\omega}}$ 16 employees who died before 1946, and 32 "no trace" employees who left employment before 1 Jan- $\frac{2}{0}$ uary 1946) make no contributions to observed num- is bers or to any expectations. Forty eight employees $\overrightarrow{0}$ untraced by the OPCS were traced alive on 30 June $\overrightarrow{-}$ 1980 at the central offices of the Department of $\bar{\sigma}$ Health and Social Security at Newcastle. No further $\triangle$ follow up has been obtained for this group of $\frac{\Phi}{3}$ employees.

Detailed job histories-defined in terms of some 75 jobs-were coded for each worker. These job histories $\vec{N}$ have recently been updated to the closing date of the survey. Eight jobs (relating to the platemaking, $\omega$ assembly, and negative active material departments) 을 were considered to entail high exposure to cadmium, 14 to entail moderate (or slight) exposure, and 53 to entail minimal (or zero) exposure (see appendix). For $\varnothing$ each worker and for each year from date of starting 3 employment the cumulative duration of high $\stackrel{\mathbb{}}{-}$ exposure employment and high or moderate exposure $\overrightarrow{0}$ employment were calculated (figure).

\section{Methods}

\section{EXTERNAL STANDARD}

The mortality of this cohort was compared with that

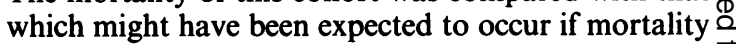
for the general population of England and Wales had $\overrightarrow{\overrightarrow{0}}$ been operating on the study cohort, having due 3 regard to the composition of the study cohort by age, sex, and calendar year. Expected numbers of deaths? were calculated using the MANYEARS program $\bar{O}$ developed by Peto.

Individuals entered the person-years at risk (PYR) at the end of the one month minumum period of 3 . employment or 1 January 1946, whichever was the 8 later date, and left the PYR on the closing date of $\risingdotseq$ survey, date of death, date of embarkation, or date $\mathrm{O}$ lost to follow up, whichever was the earliest.

Individuals were "censored" on reaching their 85th음 birthday-that is, no contributions are made to observed numbers or to expectations after this age. O

INTERNAL STANDARD

Internal comparisons of the mortality of subgroups defined in terms of duration of employment in exposed jobs were made using the Mantel-Haenszel $\stackrel{0}{\circ}$ approach applied to prospective studies. ${ }^{67}$ For these $\stackrel{\Phi}{+}$ 
Table 2 Study cohort by levels of controlling variables (totals in subgroups with numbers of deaths)

\begin{tabular}{|c|c|c|c|c|c|c|c|}
\hline \multirow[b]{2}{*}{ Age at starting employment } & \multirow[b]{2}{*}{ Sex } & \multicolumn{6}{|c|}{ Year of starting employment } \\
\hline & & $1923-$ & 1930 & 1940 & $1947-$ & $1957-$ & $\geqslant 1967$ \\
\hline $15-$ & $\begin{array}{l}\mathbf{M} \\
\mathbf{F}\end{array}$ & $\begin{array}{c}69 / 35 \\
0 / 0\end{array}$ & $\begin{array}{c}271 / 53 \\
3 / 0\end{array}$ & $\begin{array}{l}86 / 16 \\
51 / 5\end{array}$ & $\begin{array}{l}30 / 0 \\
18 / 0\end{array}$ & $\begin{array}{r}57 / 1 \\
7 / 0\end{array}$ & $\begin{array}{r}16 / 0 \\
0 / 0\end{array}$ \\
\hline $20-$ & $\begin{array}{l}\mathrm{M} \\
\mathrm{F}\end{array}$ & $\begin{array}{c}53 / 34 \\
0 / 0\end{array}$ & $\begin{array}{c}103 / 39 \\
0 / 0\end{array}$ & $\begin{array}{r}36 / 14 \\
9 / 12\end{array}$ & $\begin{array}{c}104 / 12 \\
53 / 1\end{array}$ & $\begin{array}{r}113 / 5 \\
20 / 0\end{array}$ & $\begin{array}{r}119 / 0 \\
0 / 0\end{array}$ \\
\hline $25-$ & $\begin{array}{l}\mathbf{M} \\
\mathbf{F}\end{array}$ & $\begin{array}{c}11 / 11 \\
0 / 0\end{array}$ & $\begin{array}{c}79 / 30 \\
2 / 1\end{array}$ & $\begin{array}{l}40 / 13 \\
36 / 10\end{array}$ & $\begin{array}{l}90 / 20 \\
26 / 1\end{array}$ & $\begin{array}{r}89 / 5 \\
6 / 0\end{array}$ & $\begin{array}{r}75 / 2 \\
3 / 0\end{array}$ \\
\hline $30-$ & $\begin{array}{l}\mathbf{M} \\
\mathbf{F}\end{array}$ & $\begin{array}{l}2 / 2 \\
1 / 1\end{array}$ & $\begin{array}{c}39 / 27 \\
0 / 0\end{array}$ & $\begin{array}{l}47 / 22 \\
27 / 14\end{array}$ & $\begin{array}{l}79 / 20 \\
13 / 0\end{array}$ & $\begin{array}{r}56 / 5 \\
6 / 0\end{array}$ & $\begin{array}{r}38 / 0 \\
3 / 0\end{array}$ \\
\hline $35-$ & $\begin{array}{l}\mathbf{M} \\
\mathbf{F}\end{array}$ & $\begin{array}{l}2 / 2 \\
0 / 0\end{array}$ & $\begin{array}{c}21 / 14 \\
0 / 0\end{array}$ & $\begin{array}{l}65 / 53 \\
15 / 9\end{array}$ & $\begin{array}{c}151 / 80 \\
24 / 7\end{array}$ & $\begin{array}{l}96 / 21 \\
21 / 2\end{array}$ & $\begin{array}{r}72 / 4 \\
4 / 0\end{array}$ \\
\hline $45-$ & $\begin{array}{l}\mathbf{M} \\
\mathbf{F}\end{array}$ & $\begin{array}{l}0 / 0 \\
0 / 0\end{array}$ & $\begin{array}{l}4 / 2 \\
2 / 0\end{array}$ & $\begin{array}{l}8 / 6 \\
0 / 0\end{array}$ & $\begin{array}{l}80 / 56 \\
13 / 7\end{array}$ & $\begin{array}{l}79 / 35 \\
13 / 3\end{array}$ & $\begin{array}{r}45 / 6 \\
9 / 0\end{array}$ \\
\hline$\geqslant 55$ & $\begin{array}{l}\mathbf{M} \\
\mathrm{F}\end{array}$ & $\begin{array}{l}0 / 0 \\
0 / 0\end{array}$ & $\begin{array}{l}0 / 0 \\
0 / 0\end{array}$ & $\begin{array}{l}6 / 4 \\
1 / 0\end{array}$ & $\begin{array}{l}6 / 5 \\
2 / 1\end{array}$ & $\begin{array}{c}25 / 20 \\
3 / 1\end{array}$ & $\begin{array}{r}27 / 8 \\
1 / 0\end{array}$ \\
\hline
\end{tabular}

$\mathrm{x} / \mathrm{y}$ where $\mathrm{x}=$ total in subgroup; $\mathrm{y}=$ number that die in study period among the $\mathrm{x}$ entrants.

analyses, no reference is made to mortality in the general population.

The data were first divided into 84 subcohorts by all combinations of levels of the "controlling variables." In this analysis controlling variables were sex, year of starting employment (1923-, 1930-, 1940-, 1947-, 1957-, $\geqslant 1967)$, and age at starting employment $(15-, 20-, 25-, 30-, 35-, 45-, \geqslant 55)$ (table 2). We excluded 113 workers whose job histories were either not available or inadequately described and 66 workers whose vital status was unknown at the end of the first year of being in the observational field (see end of section). Five exposure categories were considered (no exposure, and $<2,2-4,5-14$, and $\geqslant 15$ years of exposed employment) and for each subcohort and for each successive year from date of starting employment, a $2 \times 5$ table was constructed (the first row of the table showing numbers of deaths from the cause under investigation in each exposure category (column of the table), and the second row showing numbers of survivors together with those dying from other causes).

Assuming a null hypothesis of no association betweeen mortality and duration of exposed employment, we calculate expectations using the standard procedure for contingency tables. By definition, the total observed numbers of deaths equals the sum of the expectations.

Observed and expected numbers were summed over all years of follow up and over all subcohorts to provide total observed and expected numbers of cause specific deaths for each exposure category. The statistical significance of the difference between such observed and expected numbers was calculated, as was the statistical significance of any trend for the risk of death to increase or decrease progressively over exposure categories. The trend statistic is asymptotically normally distributed (a value greater than
1.96 indicates statistical significance at the $5 \%$ level, two tailed test). Two trend statistics were calculated, a linearly weighted statistic (exposure categories scored $1,2,3,4$, and 5) and a dose weighted statistic (exposure categories scored $0.0,1 \cdot 0,3.0,8.0$, and 18.0). There is no necessary implication in using the first procedure for the exposure groupings to be equally spaced. ${ }^{6}$ A Mantel-Haenszel estimate of the overall relative risk in each exposure category compared with that of unity in the "no exposure" category was also obtained.

For individuals starting employment before 1946, the data are "left censored"- that is individuals enter the life table in the "year from date of starting employment" which includes the date 1 January 1946 (the start of the observational field). For individuals "withdrawn alive" from the survey, the data are "right-censored," and the approach adopted here is that individuals leave the life table at the end of the last completed year of follow up.

\section{Results}

\section{EXTERNAL STANDARD}

Observed and expected number of deaths are shown for "early" and "late" workers by years from first employment for all causes, all neoplasms, and lung cancer in tables 3,4 , and 5 respectively.

The overall SMR for all causes is 100 (early workers, SMR = 96; late workers, SMR = 107). For early workers, there is a tendency for SMRs to decrease with successive periods from first employment, for late workers the tendency is in the opposite direction.

The overall SMR for all neoplasms is 111 (early workers, $\mathrm{SMR}=105$; late workers, $\mathrm{SMR}=119)$. The overall SMR for lung cancer is also higher among late workers $(\mathrm{SMR}=136)$ than among early workers $($ SMR $=126)$. Among late workers, there is, for all 
Table 3 Mortality from all causes: 1946-84 by successive periods from first employment, men and women combined

\begin{tabular}{|c|c|c|c|c|c|c|c|c|c|}
\hline \multirow[b]{2}{*}{ Years from first employment* } & \multicolumn{3}{|c|}{ Early workers $\dagger$} & \multicolumn{3}{|c|}{ Late workers $\ddagger$} & \multicolumn{3}{|l|}{ Total } \\
\hline & $\overline{E \S}$ & $O$ & $(S M R)$ & $\overline{E \S}$ & $O$ & $(S M R)$ & $\overline{E \S}$ & $O$ & $(S M R)$ \\
\hline $\begin{array}{l}0- \\
10- \\
20- \\
30- \\
\geqslant 40\end{array}$ & $\begin{array}{r}19 \cdot 9 \\
55 \cdot 2 \\
99 \cdot 4 \\
162 \cdot 8 \\
177 \cdot 5\end{array}$ & $\begin{array}{r}22 \\
53 \\
95 \\
156 \\
167\end{array}$ & $\begin{array}{r}(111) \\
(96) \\
(96) \\
(96) \\
(94)\end{array}$ & $\begin{array}{r}72 \cdot 3 \\
110 \cdot 7 \\
102 \cdot 0 \\
35 \cdot 2 \\
-\end{array}$ & $\begin{array}{r}69 \\
122 \\
110 \\
42 \\
-\end{array}$ & $\begin{array}{l}(95) \\
(110) \\
(108) \\
(119) \\
-\end{array}$ & $\begin{array}{l}92 \cdot 2 \\
165 \cdot 9 \\
201 \cdot 4 \\
198 \cdot 0 \\
177 \cdot 5\end{array}$ & $\begin{array}{r}91 \\
175 \\
205 \\
198 \\
167\end{array}$ & $\begin{array}{r}(99) \\
(105) \\
(102) \\
(100) \\
(94)\end{array}$ \\
\hline Total & $514 \cdot 8$ & 493 & (96) & $320 \cdot 2$ & 343 & $(107)$ & $835 \cdot 0$ & 836 & $(100)$ \\
\hline
\end{tabular}

*Irrespective of how long any individual remains in the industry.

tEarly workers, first employed 1923-46, pre-amalgamation.

†Late workers, first employed 1947-75, post-amalgamation.

$\$$ Calculated on the basis of age, sex, and calendar year specific rates of mortality for England and Wales 1946-83. No contributions made to observed numbers or expectations after 85 th birthday.

Table 4 Mortality from all neoplasms (ICD 8: 140-239): 1946-84 by successive periods from first employment, men and women combined

\begin{tabular}{|c|c|c|c|c|c|c|c|c|c|}
\hline \multirow[b]{2}{*}{ Years from first employment* } & \multicolumn{3}{|c|}{ Early workers $\dagger$} & \multicolumn{3}{|c|}{ Late workers $\ddagger$} & \multicolumn{3}{|l|}{ Total } \\
\hline & $E \S$ & $O$ & $(S M R)$ & $E \S$ & $O$ & $(S M R)$ & $\overline{E \S}$ & $O$ & $(S M R)$ \\
\hline $\begin{array}{l}0- \\
10- \\
20- \\
30- \\
\geqslant 40\end{array}$ & $\begin{array}{r}3.9 \\
12 \cdot 6 \\
25 \cdot 8 \\
45 \cdot 5 \\
48.7\end{array}$ & $\begin{array}{r}1 \\
10 \\
29 \\
44 \\
60\end{array}$ & $\begin{array}{r}(26) \\
(79) \\
(112) \\
(97) \\
(123)\end{array}$ & $\begin{array}{c}19 \cdot 3 \\
31 \cdot 1 \\
28.2 \\
9.8 \\
-\end{array}$ & $\begin{array}{l}20 \\
34 \\
35 \\
16 \\
-\end{array}$ & $\begin{array}{l}(104) \\
(109) \\
(124) \\
(163) \\
-\end{array}$ & $\begin{array}{l}23 \cdot 2 \\
43 \cdot 7 \\
54 \cdot 0 \\
55 \cdot 3 \\
48 \cdot 7\end{array}$ & $\begin{array}{l}21 \\
44 \\
64 \\
60 \\
60\end{array}$ & $\begin{array}{l}(91) \\
(101) \\
(119) \\
(108) \\
(123)\end{array}$ \\
\hline Total & $136 \cdot 5$ & 144 & $(105)$ & $88 \cdot 4$ & 105 & (119) & $224 \cdot 9$ & 249 & $(111)$ \\
\hline
\end{tabular}

For footnotes, see table 3 .

Table 5 Mortality from cancer of the lung and bronchus (ICD 8: 162, 163): 1946-84 by successive periods from first employment, men and women combined

\begin{tabular}{|c|c|c|c|c|c|c|c|c|c|}
\hline \multirow[b]{2}{*}{ Years from first employment ${ }^{*}$} & \multicolumn{3}{|c|}{ Early workers $\dagger$} & \multicolumn{3}{|c|}{ Late workers $\ddagger$} & \multicolumn{3}{|l|}{ Total } \\
\hline & $\overline{E \S}$ & $O$ & $(S M R)$ & $\overline{E \S}$ & $O$ & $(S M R)$ & $\overline{E \S}$ & $O$ & $(S M R)$ \\
\hline $\begin{array}{l}0- \\
10- \\
20- \\
30- \\
\geqslant 40\end{array}$ & $\begin{array}{r}1.0 \\
3.8 \\
9.3 \\
17.6 \\
19.8\end{array}$ & $\begin{array}{l}0 \\
2 \\
17^{*} \\
19 \\
27\end{array}$ & $\begin{array}{r}(0) \\
(53) \\
(183) \\
(108) \\
(136)\end{array}$ & $\begin{array}{r}7.0 \\
11.8 \\
10 \cdot 6 \\
3.6 \\
-\end{array}$ & $\begin{array}{c}8 \\
14 \\
14 \\
9 * \\
-\end{array}$ & $\begin{array}{l}(114) \\
(119) \\
(132) \\
(250) \\
-\end{array}$ & $\begin{array}{r}8.0 \\
15.6 \\
19.9 \\
21.2 \\
19.8\end{array}$ & $\begin{array}{c}8 \\
16 \\
31^{*} \\
28 \\
27\end{array}$ & $\begin{array}{l}(100) \\
(103) \\
(156) \\
(132) \\
(136)\end{array}$ \\
\hline Total & $51 \cdot 5$ & 65 & (126) & $33 \cdot 0$ & 45 & (136) & $84 \cdot 5$ & $110^{* *}$ & (130) \\
\hline
\end{tabular}

${ }^{*} \mathrm{p}<0.05 ;{ }^{* *} \mathrm{p}<0.01$

For footnotes, see table 3 .

Table 6 Mantel-Haenszel analysis*: test factor is cumulative duration of employment in a high exposure job, mortality 1946-84

\begin{tabular}{|c|c|c|c|c|c|c|c|c|c|}
\hline \multirow[b]{2}{*}{ Case of death } & \multirow[b]{2}{*}{ Test factor } & \multicolumn{7}{|c|}{$\begin{array}{l}\text { Cumulative } \\
\text { duration (years) of high exposure employment }\end{array}$} & \multirow[b]{2}{*}{$\chi^{2}$ for homogeneity } \\
\hline & & No exposure & $<2$ & $2-$ & $5-$ & $\geqslant 15$ & Total & Trend statistic $\ddagger$ & \\
\hline All causes & $\begin{array}{l}\text { Observed } \\
\text { Expected } \\
\text { Relative risk } \dagger\end{array}$ & $\begin{array}{l}486 \\
502 \cdot 6 \\
1.0\end{array}$ & $\begin{array}{r}125^{*} \\
106.6 \\
1.2\end{array}$ & $\begin{array}{l}44 \\
39 \cdot 7 \\
1 \cdot 2\end{array}$ & $\begin{array}{l}38 \\
39 \cdot 1 \\
1 \cdot 0\end{array}$ & $\begin{array}{l}31 \\
36 \cdot 0 \\
0.9\end{array}$ & 724 & $0.13(-0.63)$ & $5 \cdot 54$ \\
\hline $\begin{array}{l}\text { All cancers } \\
\quad(\text { ICD 8:140-209) }\end{array}$ & $\begin{array}{l}\text { Observed } \\
\text { Expected } \\
\text { Relative risk } \dagger\end{array}$ & $\begin{array}{r}146 \\
151.8 \\
1.0\end{array}$ & $\begin{array}{l}38 \\
34 \cdot 2 \\
1 \cdot 2\end{array}$ & $\begin{array}{l}15 \\
13 \cdot 1 \\
1 \cdot 2\end{array}$ & $\begin{array}{l}11 \\
10 \cdot 4 \\
1 \cdot 1\end{array}$ & $\begin{array}{l}10 \\
10.5 \\
1.0\end{array}$ & 220 & $0.47(0.09)$ & $1 \cdot 10$ \\
\hline $\begin{array}{l}\text { Lung cancers } \\
\text { (ICD 8:162, 163) }\end{array}$ & $\begin{array}{l}\text { Observed } \\
\text { Expected } \\
\text { Relative risk } \dagger\end{array}$ & $\begin{array}{l}64 \\
70 \cdot 2 \\
1 \cdot 0\end{array}$ & $\begin{array}{l}19 \\
15 \cdot 6 \\
1 \cdot 4\end{array}$ & $\begin{array}{l}6 \\
5 \cdot 3 \\
1 \cdot 3\end{array}$ & $\begin{array}{l}6 \\
4 \cdot 9 \\
1 \cdot 3\end{array}$ & $\begin{array}{l}6 \\
5 \cdot 2 \\
1 \cdot 5\end{array}$ & 101 & $1.07(0.72)$ & 1.96 \\
\hline
\end{tabular}


Table 7 Mantel-Haenszel analysis*: test factor is cumulative duration of employment in a high exposure job, mortality 1946-84: cancers of the lung and bronchus (ICD 8: 162, 163) for early and late workers

\begin{tabular}{|c|c|c|c|c|c|c|c|c|c|}
\hline \multirow[b]{2}{*}{ Subgroup } & \multirow[b]{2}{*}{ Test factor } & \multicolumn{7}{|c|}{$\begin{array}{l}\text { Cumulative } \\
\text { duration (years) of high exposure employment }\end{array}$} & \multirow[b]{2}{*}{$\chi^{2}$ for homogeneity } \\
\hline & & No exposure & $<2$ & $2-$ & $5-$ & $\geqslant 15$ & Total & Trend statistic $\ddagger$ & \\
\hline Early workers & $\begin{array}{l}\text { Observed } \\
\text { Expected } \\
\text { Relative risk } †\end{array}$ & $\begin{array}{l}40 \\
41 \cdot 3 \\
1 \cdot 0\end{array}$ & $\begin{array}{l}5 \\
8 \cdot 9 \\
0 \cdot 6\end{array}$ & $\begin{array}{l}5 \\
2 \cdot 7 \\
2 \cdot 0\end{array}$ & $\begin{array}{l}5 \\
3.0 \\
1.7\end{array}$ & $\begin{array}{l}4 \\
3 \cdot 2 \\
1 \cdot 4\end{array}$ & 59 & $1 \cdot 18(1 \cdot 03)$ & $5 \cdot 44$ \\
\hline $\begin{array}{l}\text { Early workers with } \\
\text { lagged exposures§ }\end{array}$ & $\begin{array}{l}\text { Observed } \\
\text { Expected } \\
\text { Relative risk } \dagger\end{array}$ & $\begin{array}{l}41 \\
41 \cdot 7 \\
1.0\end{array}$ & $\begin{array}{l}5 \\
9 \cdot 0 \\
0 \cdot 6\end{array}$ & $\begin{array}{l}4 \\
2.6 \\
1.5\end{array}$ & $\begin{array}{l}7 \\
3 \cdot 3 \\
2 \cdot 4\end{array}$ & $\begin{array}{l}2 \\
2.4 \\
0.9\end{array}$ & & $1.02(0.77)$ & 6.93 \\
\hline Late workers & $\begin{array}{l}\text { Observed } \\
\text { Expected } \\
\text { Relative risk } \dagger\end{array}$ & $\begin{array}{l}24 \\
28 \cdot 9 \\
1 \cdot 0\end{array}$ & $\begin{array}{c}14 * * * \\
6 \cdot 7 \\
2 \cdot 7\end{array}$ & $\begin{array}{l}1 \\
2.5 \\
0.5\end{array}$ & $\begin{array}{l}1 \\
1.9 \\
0.6\end{array}$ & $\begin{array}{l}2 \\
1.9 \\
1.7\end{array}$ & 42 & $0.25(-0.15)$ & $10.68^{*}$ \\
\hline
\end{tabular}

$* \mathrm{p}<0.05 ;^{* * *} \mathrm{p}<0.001$

,+ \pm See footnotes table 6 .

Exposures are lagged by 10 years. Deaths occurring in the first ten years from date of starting employment are uninformative and are ignored.

neoplasms and for lung cancer, a regular trend of SMRs increasing with successive periods from first employment.

The overall SMR for all neoplasms other than lung cancer is 97 (early workers, SMR $=93$; late workers, SMR = 103).

\section{INTERNAL STANDARD}

With exposure estimated as duration of employment in high exposure jobs, the trend statistic (linearly weighted) for the risk of death from all causes to increase (or decrease) progressively over exposure categories was close to zero (table 6). The chi-square for homogeneity was also unexceptional. Similar results were also obtained for all cancers. A larger trend statistic was obtained for lung cancer, although this statistic did not approach a level of statistical significance $(p=0.3)$.

These analyses were repeated with exposures "lagged" by 10 years. (One consequence of this is that deaths in the first 10 years from starting employment are uninformative and are ignored.) The trend statistic for lung cancer was reduced from 1.07 to 0.65 .

For deaths from lung cancer, the analysis was car- ried out separately for early workers and for late workers (table 7). The trend statistic obtained for late workers was close to zero. For the three highest exposure categories combined, there were four observed deaths and an expectation of 6.3. The chi-square for homogeneity was statistically significant at the $5 \%$ level $\left(\chi^{2}=10 \cdot 68\right)$, with a high relative risk being found in the second exposure category $(R R=2 \cdot 7)$.

The above analyses were repeated for a second exposure estimate-namely, duration of employment in a high or moderate exposure job.

Findings for all causes and for lung cancer are shown in table 8 . Trend statistics are close to zero, although for lung cancer a relative risk of 1.7 is found in the highest exposure category. These analyses were repeated with exposure lagged by 10 years. The trend statistic for lung cancer was increased from 0.37 to 0.47 .

For lung cancer, these analysis were also carried out separately for early workers and late workers (table 9). For early workers, the trend statistic approached the level of statistical significance and a statistically significant difference between observed

Table 8 Mantel-Haenszel analysis*: test factor is cumulative duration of employment in a high or moderate exposure job, mortality 1946-84

\begin{tabular}{|c|c|c|c|c|c|c|c|c|c|}
\hline \multirow[b]{2}{*}{ Cause of death } & \multirow[b]{2}{*}{ Test factor } & \multicolumn{7}{|c|}{$\begin{array}{l}\text { Cumulative } \\
\text { duration (years) of high exposure employment }\end{array}$} & \multirow[b]{2}{*}{$\chi^{2}$ for homogeneity } \\
\hline & & No exposure & $<2$ & $2-$ & $5-$ & $\geqslant 15$ & Total & Trend statistic $\ddagger$ & \\
\hline All causes & $\begin{array}{l}\text { Observed } \\
\text { Expected } \\
\text { Relative risk } \dagger\end{array}$ & $\begin{array}{l}321 \\
328 \cdot 7 \\
1.0\end{array}$ & $\begin{array}{l}201 \\
188 \cdot 2 \\
1 \cdot 1\end{array}$ & $\begin{array}{l}74 \\
79 \cdot 6 \\
0.9\end{array}$ & $\begin{array}{l}75 \\
74 \cdot 6 \\
1 \cdot 1\end{array}$ & $\begin{array}{l}66 \\
65 \cdot 9 \\
1 \cdot 1\end{array}$ & 737 & $0 \cdot 10(0.01)$ & 1.56 \\
\hline $\begin{array}{l}\text { Lung cancer } \\
\text { (ICD 8: 162, 163) }\end{array}$ & $\begin{array}{l}\text { Observed } \\
\text { Expected } \\
\text { Relative risk } \dagger\end{array}$ & $\begin{array}{l}46 \\
44 \cdot 3 \\
1 \cdot 0\end{array}$ & $\begin{array}{l}26 \\
26 \cdot 8 \\
0.9\end{array}$ & $\begin{array}{c}7 \\
10 \cdot 7 \\
0 \cdot 5\end{array}$ & $\begin{array}{c}8 \\
10 \cdot 2 \\
0 \cdot 7\end{array}$ & $\begin{array}{l}15 \\
10 \cdot 1 \\
1 \cdot 7\end{array}$ & 102 & $0.37(1 \cdot 11)$ & 4.69 \\
\hline
\end{tabular}

*, $\uparrow,{ }_{+}^{+}$See footnotes table 6. 
Table 9 Mantel-Haenszel analysis*: test factor is cumulative duration of employment in a high or moderate exposure job. Mortality 1946-84: cancers of the lung and bronchus (ICD 8: 162, 163) for early and late workers

\begin{tabular}{|c|c|c|c|c|c|c|c|c|c|}
\hline \multirow[b]{2}{*}{ Subgroup } & \multirow[b]{2}{*}{ Test factor } & \multicolumn{7}{|c|}{$\begin{array}{l}\text { Cumulative } \\
\text { duration (years) of high exposure employment }\end{array}$} & \multirow[b]{2}{*}{$\chi^{2}$ for homogeneity } \\
\hline & & No exposure & $<2$ & $2-$ & $5-$ & $\geqslant 15$ & Total & Trend statistic $\ddagger$ & \\
\hline Early workers & $\begin{array}{l}\text { Observed } \\
\text { Expected } \\
\text { Relative risk } \dagger\end{array}$ & $\begin{array}{l}27 \\
28 \cdot 3 \\
1 \cdot 0\end{array}$ & $\begin{array}{l}10 \\
14 \cdot 2 \\
0 \cdot 7\end{array}$ & $\begin{array}{l}3 \\
4 \cdot 4 \\
0 \cdot 7\end{array}$ & $\begin{array}{l}7 \\
6 \cdot 3 \\
1 \cdot 2\end{array}$ & $\begin{array}{c}13 * * \\
6 \cdot 8 \\
2 \cdot 2\end{array}$ & 60 & $1.87\left(2.49^{*}\right)$ & $7 \cdot 81$ \\
\hline $\begin{array}{l}\text { Early workers with } \\
\text { lagged exposures§ }\end{array}$ & $\begin{array}{l}\text { Observed } \\
\text { Expected } \\
\text { Relative risk } \dagger\end{array}$ & $\begin{array}{l}28 \\
28 \cdot 7 \\
1.0\end{array}$ & $\begin{array}{c}9 \\
14 \cdot 5 \\
0 \cdot 6\end{array}$ & $\begin{array}{l}3 \\
4 \cdot 4 \\
0 \cdot 6\end{array}$ & $\begin{array}{r}11 \\
6.9 \\
1.8\end{array}$ & $\begin{array}{l}9 * * \\
5.5 \\
1.7\end{array}$ & 60 & $1 \cdot 77\left(2 \cdot 15^{*}\right)$ & $7 \cdot 62$ \\
\hline Late workers & $\begin{array}{l}\text { Observed } \\
\text { Expected } \\
\text { Relative risk } \dagger\end{array}$ & $\begin{array}{l}19 \\
16 \cdot 0 \\
1.0\end{array}$ & $\begin{array}{l}16 \\
12 \cdot 5 \\
1 \cdot 1\end{array}$ & $\begin{array}{l}4 \\
6 \cdot 3 \\
0 \cdot 4\end{array}$ & $\begin{array}{l}1 \\
4 \cdot 0 \\
0 \cdot 2\end{array}$ & $\begin{array}{l}2 \\
3 \cdot 2 \\
0.6\end{array}$ & 42 & $-1.89(-1.60)$ & 5.43 \\
\hline
\end{tabular}

${ }^{*} \mathrm{p}<0.05 ;{ }^{* *} \mathrm{p}<0.01$.

$\dagger, \ddagger$, §See footnotes table 6 and 7.

and expected numbers was found in the highest exposure category (expected $=6 \cdot 8$, observed $=13$ ). A negative trend statistic was obtained for late workers, indicating that there was a tendency for the risk of mortality to decrease across the exposure categories. This trend was not statistically significant. A negative trend statistic was, in fact, also obtained for all causes mortality among late workers, although it was less pronounced than that for lung cancer.

Similar analyses to the above were carried out for those employees with a minimum period of employment of one year and similar results were obtained.

\section{Discussion}

Not all the personnel records relating to workers first employed at the two original factories (1923-46) are still available for analysis. This is hardly surprising, and in fact the degree of detail and completeness of record keeping at the factory was outstandingly high.

It would be easy to postulate a tendency for the records of those early workers who remained after the amalgamation to be the records that were kept-that is, records of a "survivor population," and this hypothesis is supported by the observation of a lower overall SMR among early workers $(S M R=96)$ than among late workers $(S M R=107)$. Furthermore, there is evidence of a standard healthy worker effect in the late workers, with a tendency for overall SMRs to increase with successive periods from first employment. ${ }^{11}$ Such an effect is not shown in the early workers for whom the corresponding trend is in the opposite direction. This is also suggestive of an incomplete cohort for early workers.

The classification of jobs by degree of exposure to cadmium (see appendix) is also likely to be much more meaningful for the period 1947 onwards because firstly, the personal experience of those individuals who helped with the classification related to this period rather than to pre-1939 conditions and, secondly, in one of the early factories different jobs were carried out in the same "shop."

Thus there are two important reasons why we could place more reliance on the findings for the late workers. Nevertheless, it is also the case that the instances of highest exposure to cadmium probably occurred before 1939 .

Of the 82 deaths from cancers of the respirator system (ICD 8: 160-163) analysed in our 1983 publif cation, two were excluded from this Mantel-Haensze analysis of deaths from lung cancer because they were deaths from respiratory cancer other than lung cancer. (There were no deaths from lung cancer after the age of 84). Thus the 102 deaths from lung cancer analysed in this report (with a procedure which may be viewed as complementary to the method of regression models in life tables) include 22 deaths not previously analysed.

Among early workers, there was some evidence of an association between risk of death from lung cancer and duration of employment in high or moderate exposure jobs, but the evidence relied heavily on the findings for the highest exposure category. This observation has been reported before. ${ }^{512}$ Among late workers (the group with the higher SMR for lung cancer), there was no good evidence of an association between risk of dying from lung cancer and duration of employment in high exposure jobs, and no evidence whatsoever for an association with duration of employment in high or moderate exposure jobs.

In conclusion, these findings do not suggest that workers in this nickel cadmium battery factory experienced raised risks of dying from lung cancer as a consequence of exposure to cadmium oxide dust. 


\section{Appendix}

\section{JOB CATEGORIES BY EXPOSURE TO CADMIUM \\ High exposure}

Assembly, miniature cell assembly, small cell assembly, sintered assembly, main assembly, negative active material, platemaking, sintered platemaking.

\section{Moderate (or slight) exposure}

Maintenance, building maintenance, bricklayer, electricians, factory cleaning, inspection, millwrights, painter, pipefitting, quality control, repair shop, scrap recovery, shop sweeper, welding.

\section{Minimal (or zero) exposure}

Annealing, blacksmith, bobbin (dry cell), boilerman, canteen, cell plating, charge shop, chemical laboratory, carpenter, despatch, dry cell filling, engine driver, research and development, final assembly, formation, fork lift driver, garage, groundsman, gate duty, iron lamp assembly, lamp shop, lead mill, lead paster, machine shop, mine lamp assembly, nickel flake, nickel plating, office cleaner, offices, packing, perforating, plating, polisher, positive active material, press shop, plastic assembly, ribbon plating, shot blasting, spraying, stores, technical department, test room, tool room, transport, truck driver, tube assembly, tube department, van driver, woodshop warehouseman, work study, yard labourer.

\section{References}

1 Lemen RA, Lee JS, Wagoner JK, Blejer HP. Cancer mortality among cadmium production workers. Ann NY Acad Sci 1979;271:273-9.

2 Thun MJ, Schnorr TM, Smith AB, Halperin WE, Lemen RA. Mortality among a cohort of US cadmium production workers-an update. JNCI 1985;74:325-33.

3 Holden H. Further mortality studies in workers exposed to cadmium fume. In: Occupational exposure to cadmium. London: Cadmium Association, 1980:23-4.

4 Armstrong BG, Kazantzis G. A mortality study of cadmium workers. Lancet 1983;i:1425-7.

5 Sorahan T, Waterhouse JAH. A mortality study of nickelcadmium battery workers by the method of regression models in life-tables. Br J Ind Med 1983;40:293-300.

6 Mantel N. Chi-square tests with one degree of freedom: extensions of the Mantel-Haenszel procedure. Journal of the American Statistical Association 1963;58:690-700.

7 Mantel N. Evaluation of survival data and two new rank statistics arising in its consideration. Journal of the American Statistical Association 1963;58:690-700.

8 Potts CL. Cadmium proteinuria-the health of battery workers exposed to cadmium oxide dust. Ann Occup Hyg 1985;8:55-61.

9 Adams RG, Harrison JF, Scott P. The development of cadmiuminduced proteinuria, impaired renal function and osteomalacia in alkaline battery workers. $Q J$ Med 1969;38:425-43.

10 Sorahan T. A mortality study of nickel-cadmium battery workers. In: Proceedings of the third International Cadmium Conference, Miami, 1981. London and New York: Cadmium Association, Cadmium Council, and ILZRO, 1982.

11 Fox AJ, Collier PF. Low mortality rates in industrial cohort studies due to selection for work and survival in the industry. $\mathrm{Br} J$ Prev Soc Med 1976;30:225-30.

12 Sorahan T. A further mortality study of nickel-cadmium battery workers. In: Proceedings of the fourth International Cadmium Conference, Munich, 1983. London and New York: Cadmium Association, Cadmium Council, and ILZRO, 1984.

\section{Destruction of manuscripts}

From 1 July 1985 articles submitted for publication will not be returned. Authors whose papers are rejected will be advised of the decision and the manuscripts will be kept under security for three months to deal with any inquiries and then destroyed. 